\title{
Serological Relationships Between Strains of Anaerobic Mycoplasmas
}

\author{
ISADORE M. ROBINSON AND KEITH R. RHOADES
}

\author{
National Animal Disease Center, Agricultural Research Service, Ames, Iowa 50010
}

Ten obligately anaerobic mycoplasma strains isolated from the rumen of sheep and cattle were grouped serologically by agglutination and gel diffusion precipitin tests. They could be placed into four serovars that fit well with group separations based upon cultural, biochemical, and biophysical properties. $\mathrm{Hy}$ perimmune sera prepared against a strain representing each serovar showed no cross-species interaction when tested with antigens of several known aerobic bovine mycoplasma and acholeplasma strains. Growth inhibition tests of Anaeroplasma strains confirmed the grouping by agglutination and gel diffusion precipitin tests.

Both sterol- and non-sterol-requiring strains of obligately anaerobic mycoplasma have been isolated from the rumen of sheep and cattle $(10,11)$. These organisms were placed in a new genus, Anaeroplasma (11), and have cultural and metabolic properties that distinguish them from previously reported bovine mycoplasmas (1). In this paper the results of experiments conducted to determine the serological relationships of strains of anaeroplasmas to each other and to some known bovine mycoplasmas are reported.

\section{MATERIALS AND METHODS}

Ten anaerobic mycoplasma strains representative of three groups separated on the basis of cultural, biophysical, and metabolic properties $(10,11)$ were used for serological differentiation (Table 1). Strain $\mathrm{JR}$, isolated from ruminal contents of cattle (J. P. Robinson, Diss. Abstr. Int. 32:7196B, 1972), was obtained from J. Robinson. The rest of the Anaeroplasma strains were isolated from ruminal contents of sheep $(10,11)$.

Preparation of antigen. Antigens were prepared from cells grown in clarified rumen fluid broth medium (11). Cells were sedimented by centrifugation at $10,000 \times g$ for $15 \mathrm{~min}$. They were then washed twice with $0.85 \%$ sodium chloride, buffered to $\mathrm{pH} 7.2$ with $0.02 \mathrm{M}$ sodium phosphate (PBS), and suspended in PBS at a concentration appropriate for their intended use. The concentrations were adjusted spectrophotometerically as multiples of a standard at 0.1 optical density in $16-\mathrm{mm}$ tubes with a Coleman Junior spectrophotometer at $600 \mathrm{~nm}$ (no. $1 \mathrm{McF}$ arland tube). The concentrations of antigens used for the agar gel diffusion tests and the plate agglutination tests were 40 times and 20 times the standard concentration, respectively. The concentration of antigens used for the tube agglutination tests was the same as that of the standard. Antigens used to produce antibody in rabbits were adjusted to 30 times the standard concentration and emulsified with an equal volume of Freund complete adjuvant.
Strains representing 12 of the known 13 bovine mycoplasma and acholeplasma serovars (1) were obtained from W. H. Kelton (now deceased) of the National Animal Disease Center, Ames, Iowa, and used to prepare antigens for plate agglutination test comparisons with the anaerobic mycoplasma. The serovars and representative strains were as follows: (B) PG11, (C) PG10, (D) FX1, (E) B5P, (F) B38P, (G) RLPG51, (H) B12PA, (I) MC1, (J) RPG47, (K) B74, (L) B144, and (M) B44. These strains were cultured aerobically in heart infusion broth (7), and antigens were prepared as described for the anaerobic mycoplasmas.

Production of hyperimmune serum. Antisera against Anaeroplasma strains 6-1, 7LA, JR, and 161 were prepared in rabbits. The inoculation procedure was similar to that described by Morton and Roberts (8). The sites of inoculation, amounts of inoculum, and intervals between inoculations are indicated in Table 2. Preimmunizing sera served as negative controls. Antisera against representative strains of bovine mycoplasma and acholeplasma were obtained from W. H. Kelton and D. E. Hughes of the National Animal Disease Center. Procedures similar to those described for anaerobic strains were used to produce these antisera in rabbits.

Serological test procedure. Procedures used for tube agglutination tests (13) and plate agglutination tests (9) were previously described. Procedures for the agar gel diffusion test were as described (6) except that the sodium chloride content of the agar gel was $0.85 \%$.

Growth inhibition tests. Growth inhibition tests were performed as described by Gourlay and Domermuth (4) except that growth was measured by determining the incorporation of tritiated thymidine (3). The test system contained the following: $0.50 \mathrm{ml}$ of medium MM-10 (11) supplemented with $2 \mu \mathrm{g}$ of cholesterol per $\mathrm{ml}$ and $250 \mu \mathrm{g}$ of lipopolysaccharide Boivin per $\mathrm{ml} \mathrm{(2),} 0.1 \mathrm{ml}$ of penicillin $(1,000 \mathrm{U}), 0.1$ $\mathrm{ml}$ of $\left[{ }^{3} \mathrm{H}\right]$ thymidine $(100 \mu \mathrm{Ci}, 0.52 \mu \mathrm{mol})$, and $0.2 \mathrm{ml}$ of either preimmune or hyperimmune rabbit serum. This mixture was inoculated with $0.1 \mathrm{ml}$ of an overnight culture of the test strain and incubated under anaerobic conditions. Duplicate $100-\mu l$ samples were 
TABLE 1. Composite of differential characteristics of Anaeroplasma strains ${ }^{a}$

\begin{tabular}{ccccc}
\hline $\begin{array}{c}\text { Sero- } \\
\text { var }\end{array}$ & Strain & $\begin{array}{c}\text { Bacterio- } \\
\text { lytic }\end{array}$ & $\begin{array}{c}\text { Require- } \\
\text { ment for } \\
\text { choles- } \\
\text { terol }\end{array}$ & $\begin{array}{c}\text { G+C } \\
\text { content } \\
(\mathrm{mol})\end{array}$ \\
\hline 1 & JR & + & + & 33.7 \\
2 & $5 \mathrm{LA}$ & + & + & $\mathrm{ND}^{c}$ \\
& 5LB & + & + & $\mathrm{ND}$ \\
& 5LC & + & + & $\mathrm{ND}$ \\
& $7 \mathrm{LA}$ & + & + & 32.5 \\
3 & $6-1$ & - & + & 29.3 \\
& 171 & - & + & 29.5 \\
& 161 & - & - & 40.2 \\
4 & 162 & - & - & 40.3 \\
& 163 & - & - & $\mathrm{ND}$ \\
\hline
\end{tabular}

${ }^{a}$ Cultural, biophysical, and biochemical properties (10-12).

${ }^{b} \mathrm{G}+\mathrm{C}$, Guanine plus cytosine.

${ }^{c} \mathrm{ND}$, Not done.

TABLE 2. Rabbit immunization procedures

\begin{tabular}{|c|c|c|c|}
\hline Day & $\begin{array}{l}\text { Inocula- } \\
\text { tion } \\
\text { site }^{a}\end{array}$ & $\begin{array}{c}\text { Amt of } \\
\text { inocu- } \\
\text { lum } \\
(\mathrm{ml})\end{array}$ & Remarks \\
\hline 0 & & & Preimmunization bleeding \\
\hline \multirow[t]{3}{*}{0} & FP & 0.1 & $\begin{array}{l}\text { Fleshy part of the central } \\
\text { FP of each hind leg; tota } \\
=0.2 \mathrm{ml}\end{array}$ \\
\hline & ID & 0.1 & $\begin{array}{l}\text { Three sites in the skin on } \\
\text { the back; total }=0.3 \mathrm{~m}\end{array}$ \\
\hline & IM & 0.5 & $\begin{array}{l}\text { Two sites on both shoul } \\
\text { ders; total }=2 \mathrm{ml}\end{array}$ \\
\hline 22 & IM & 0.5 & $\begin{array}{l}\text { Two sites on both shoul } \\
\text { ders; total }=2 \mathrm{ml}\end{array}$ \\
\hline 44 & IM & 0.5 & In each hip; total $=1 \mathrm{ml}$ \\
\hline $\begin{array}{l}58 \\
74\end{array}$ & IM & 0.5 & $\begin{array}{l}\text { In each hip; total }=1 \mathrm{ml} \\
\text { Final bleeding }\end{array}$ \\
\hline
\end{tabular}

${ }^{a}$ Abbreviations: FP, footpad; IM, intramuscular; and 'D, intradermal.

removed at $0,4,8,16$, and $24 \mathrm{~h}$ and placed on separate $2-\mathrm{cm}^{2}$ Whatman no. 1 filter papers. Nucleic acids were precipitated, and unmetabolized thymidine was removed from the filter paper squares as described by Byfield and Scherbaum (3). Each square was then transferred to a scintillation vial, and $15 \mathrm{ml}$ of a toluene scintillation solution (5) was added. Radioactivity was determined in a Packard scintillation counter.

\section{RESULTS}

In tube agglutination tests, 10 Anaeroplasma strains belonging to 3 biovars could be placed in 4 serological groups (Table 3). Results of plate agglutination tests agreed with those of the tube agglutination tests. Strains within each serovar showed cross-agglutination reactions, but no cross-agglutination was observed among groups. The grouping of the 10 strains by agglutination tests was substantiated by the gel diffusion precipitin test. Figures $1 \mathrm{~A}$ to $\mathrm{D}$ show the results of immune precipitation reaction between antigens JR, 6-1, 7LA, and 161 and their aitisera. The only precipitin lines that resulted from heterologous combinations of these antigens and antisera were between antigen 7LA and antisera JR and 6-1 (Fig. 1A and B). These lines did not fuse with lines resulting from homologous combinations of antigen and antibody, and no precipitin lines were observed between 7LA antisera and JR and 6-1 antigens (Fig. 1C). Figures $2 \mathrm{~A}$ to $\mathrm{C}$ show precipitin lines formed by strains within a particular serovar; these lines indicate that antigens are similar.

TABLE 3. Tube agglutination tests results ${ }^{a}$

\begin{tabular}{|c|c|c|c|c|c|}
\hline \multirow{2}{*}{ Antigens } & \multicolumn{4}{|c|}{ Antisera } & \multirow{2}{*}{$\begin{array}{c}\text { Preim- } \\
\text { mune } \\
\text { sera }\end{array}$} \\
\hline & $6-1$ & JR & 7LA & 161 & \\
\hline $6-1$ & 40 & - & - & - & - \\
\hline 171 & 320 & - & - & - & - \\
\hline JR & - & 80 & - & - & - \\
\hline 7LA & - & - & 640 & - & - \\
\hline 5LA & - & - & 1,280 & - & - \\
\hline $5 \mathrm{LB}$ & - & - & 1,280 & - & - \\
\hline $5 \mathrm{LC}$ & - & - & 1,280 & - & - \\
\hline 161 & - & - & - & 80 & - \\
\hline 162 & - & - & - & 80 & - \\
\hline 163 & - & - & - & 80 & - \\
\hline
\end{tabular}

${ }^{a}$ Values given are reciprocals of highest dilution that showed agglutination; - indicates no agglutination at lowest dilution tested (1:10).

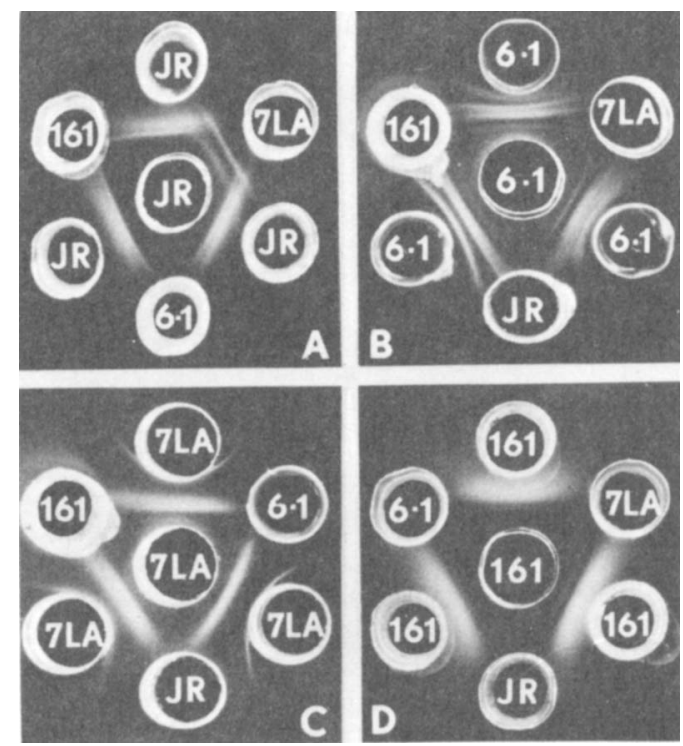

FIG. 1. Results of gel diffusion precipitin tests with antisera (center wells) and antigens (outer wells) prepared from strains representing different serovars. 


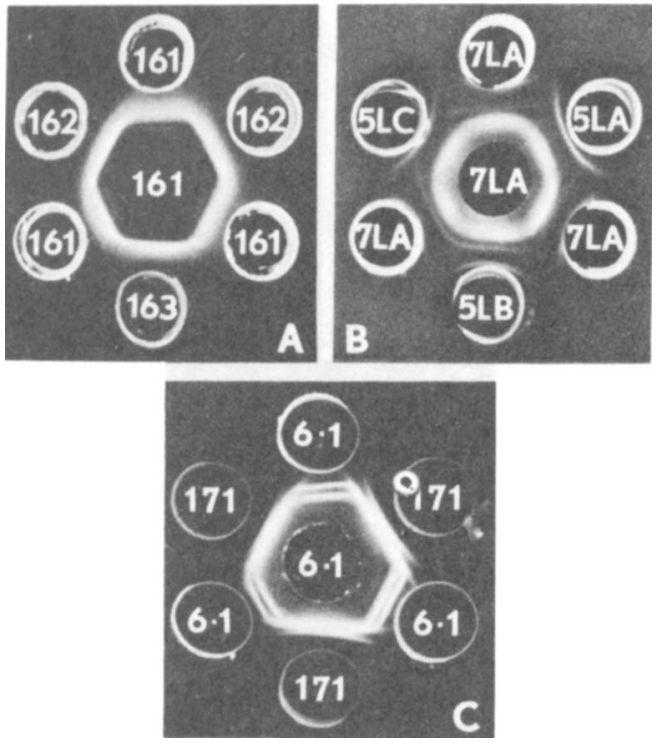

FIG. 2. Results of gel diffusion precipitin tests indicating antigenic similarities of strains within particular serovars. Antiserum was placed in the center wells; antigen was placed in the outer wells.

The bovine Mycoplasma and Acholeplasma serovars did not cross-react with any of the Anaeroplasma strains in either the tube agglutination or plate agglutination tests. Agglutination occurred with all homologous antigen and antibody combinations.

Results of the growth inhibition test confirmed the tube agglutination and agar gel diffusion test results. Strains grown in heterologous antiserum or preimmune rabbit serum showed a linear incorporation of $\left[{ }^{3} \mathrm{H}\right]$ thymidine (Fig. 3). Rabbit antiserum prepared against strain 6-1 inhibited growth of strains 171 and 61 but not of strain 161; these results indicate that strain 6-1 and 171 are serologically related but that strain 161 is not related to strain 6-1.

\section{DISCUSSION}

Agreement between the grouping of obligately anaerobic mycoplasma strains serologically and biochemically was close except for strain JR, which resembles the other lytic mycoplasma strains in most of the known physiological characteristics but belongs in a different group on the basis of serological characteristics. This was the only strain of Anaeroplasma in this study that was of bovine origin. Further studies are needed to compare additional bovine and ovine strains.

Growth inhibition by homologous antiserum is regarded as a characteristic property of myco-

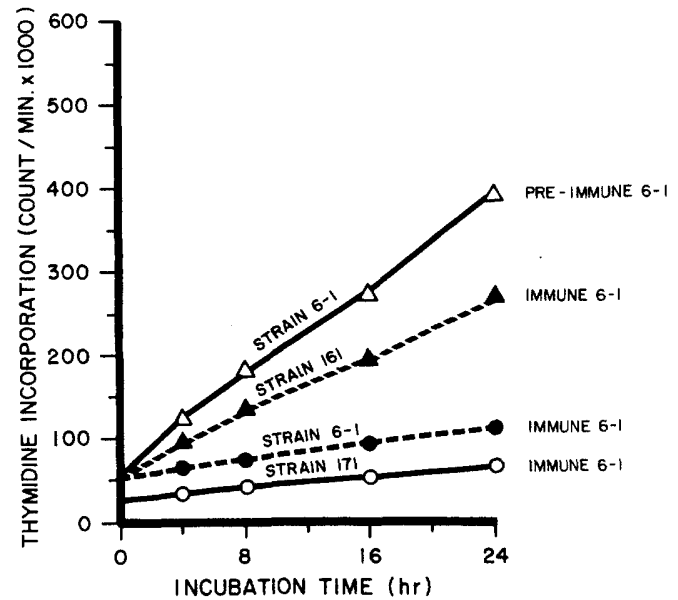

FIG. 3. Effect of preimmune or immune rabbit serum produced against strain 6-1 on growth of strains $6-1,161$, and 171, as influenced by the length of time sera and cultures are incubated. Note that there was no inhibition by preimmune serum and no inhibition of strain 161, but inhibition of strains 6-1 and 171 .

plasmas, and the results of our growth inhibition tests support the classification of these anaerobic organisms as mycoplasma. Detection of deoxyribonucleic acid synthesis by measuring $\left[{ }^{3} \mathrm{H}\right]$ thymidine incorporation was a sensitive method for measurement of growth to test for inhibition. The test is reproducible and can be readily modified and is easily performed. Results of the growth inhibition tests with strains $6-1,161$, and 171 agreed with agglutination test results and support grouping of these three strains into two serovars. Results in other studies showed that growth of strain 7LA as measured by colony-forming units was drastically inhibited when incubated with homologous hyperimmune serum but not when cells were incubated with preimmunizing rabbit serum (I. M. Robinson, M.S. thesis, Iowa State University, Ames, Iowa, 1973). The serological data thus support the uniqueness of these anaerobic mycoplasmas and our groupings based upon cultural and biochemical properties. Anaeroplasma strains are present in the rumen of cattle and sheep at concentrations of $10^{6}$ to $10^{7}$ per $\mathrm{g}$ of ruminal contents, and because we have examined only a limited number of strains, isolates belonging to other serological and physiological groups may likely be found.

\section{REPRINT REQUESTS}

Address reprint requests to: Dr. Isadore M. Robinson, National Animal Disease Center, Agricultural Research Service, Ames, Iowa 50010. 


\section{LITERATURE CITED}

1. Al-Aubaide, J, M., and J. Fabricant. 1971. Characterization and classification of bovine mycoplasma. Cornell Vet. 61:490-518.

2. Boivin, A., I. Mesrobeanu, and L. Mesrobeanu. 1933. Technique pour la preparation des polysaccharides microbiens specifiques. C. R. Soc. Biol. 113:490-492.

3. Byfield, J. E., and O. H. Scherbaum. 1966. A rapid radioassay technique for cellular suspensions. Anal. Biochem. 17:434-443.

4. Gourlay, R. N., and C. H. Domermuth. 1967. Growth inhibition and "neutralization" immune bovine serum: I. Development of a liquid medium test. Ann. N.Y. Acad. Sci. 143:325-336.

5. Hayes, F. N. 1963. Solutes and solvents for liquid scintillation counting. Packard Technical Bulletin no. 1. Packard Instrument Co., Inc., Downers Grove, Ill.

6. Heddleston, K. L., J. E. Gallagher, and P. A. Rebers. 1972. Fowl cholera: gel diffusion precipitin test for serotyping Pasteurella multocida from avian species. Avian Dis. 16:925-936.
7. Kelton, W. H., and H. VanRoekel. 1963. Serologic studies of mycoplasma (PPLO) of avian origin. Avian Dis. 7:272-286.

8. Morton, H. E., and R. J. Roberts. 1967. Production of antimycoplasma (PPLO) antibodies in rabbits. Proc. Soc. Exp. Biol. Med. 124:538-543.

9. Rhoades, K. R. 1975. Antibody responses of turkeys experimentally exposed to Mycoplasma synoviae. Avian Dis. 19:437-442.

10. Robinson, I. M., and M. J. Allison. 1975. Transfer of Acholeplasma bactoclasticum Robinson and Hungate to the genus Anaeroplasma (Anaeroplasma bactoclasticum [Robinson and Hungate] comb. nov.): emended description of the species. Int. J. Syst. Bacteriol. 25:182-186.

11. Robinson, I. M., M. J. Allison, and P. A. Hartman. 1975. Anaeroplasma abactoclasticum gen. nov., sp. nov.: an obligately anaerobic mycoplasma from the rumen. Int. J. Syst. Bacteriol. 25:173-181.

12. Yoder, H. W., Jr., and M. S. Hofstad. 1964. Characterization of avian mycoplasma. Avian Dis. 8:481-512. 